\title{
Description of the larval stages of Gymnochthebius jensenhaarupi and phylogenetic analysis of the relationships with other species of the subfamily Ochthebiinae (Coleoptera: Hydraenidae)
}

\author{
JuAN A. DELGADO ${ }^{1}$ and Miguel ARCHANGELSKY² \\ ${ }^{1}$ Departamento de Zoología y Antropología Física, Facultad de Biología, Universidad de Murcia, 30100, Murcia, Spain; \\ e-mail: jdelgado@um.es \\ ${ }^{2}$ CONICET- Facultad de Ciencias Naturales (LIESA), Universidad Nacional de La Patagonia San Juan Bosco, Sarmiento 849, \\ 9200 Esquel, Chubut, Argentina; e-mail: hydrophilidae@hotmail.com
}

Key words. Coleoptera, Hydraenidae, Ochthebiinae, Gymnochthebius, larvae, chaetotaxy, phylogeny, Argentina, Neotropics

\begin{abstract}
The three larval instars of Gymnochthebius jensenhaarupi (Knisch, 1924) are described and illustrated, including a detailed analysis of their chaetotaxy and porotaxy. The specimens used in this study were collected with adults of G. jensenhaarupi and have been identified as such by association. Comparative notes on the morphology of these larvae with other species of the subfamily Ochthebiinae are given. A hypothesis of phylogenetic relationships between G. jensenhaarupi and other members of Ochthebiinae with thoroughly described larvae is presented. The monophyly of Ochthebiinae is supported by additional larval features. On the other hand Ochthebius, as currently composed, seems to by paraphyletic. Gymnochthebius Orchymont, 1943 is confirmed as the sister group of Aulacochthebius Kuwert, 1887.
\end{abstract}

\section{INTRODUCTION}

Gymnochthebius Orchymont, 1943 is a genus of Hydraenidae composed by thirty-one species. Most of them are endemic to the Neotropical (20) or Australian (6) regions and a few (3) are known exclusively from the Nearctic region. The two remaining species have a wide American distribution and they are found both in the Neotropical and Nearctic realms (Hansen, 1998; Perkins \& Archangelsky, 2002). As some other ochthebiine genera Gymnochthebius was originally proposed as a subgenus of Ochthebius Leach, 1815 but was convincingly considered as a distinct genus by Perkins (1980). Hansen (1991) pointed out morphological similarities between adults of Gymnochthebius and Aulacochthebius Kuwert, 1887, but it was Perkins (1997) who explicitly postulated a close phylogenetic relationship between both genera (along with Gymnanthelinus Perkins, 1997) in a lineage comprising also the genera Ochthebius, Hughleechia Perkins, 1981 and Micragasma Sahlberg, 1900 within the subfamily Ochthebiinae. Unfortunately, this close phylogenetic relationships could not be tested in Beutel et al. (2003) since these authors did not include Aulacochthebius in their cladistic study.

As in many other groups of Hydraenidae, the immature of Gymnochthebius are poorly known, thus these stages have been of little help until now both in taxonomic and in phylogenetic studies. Richmond (1920) studied the larva of G. fossatus (LeConte, 1855) (under Ochthebius tuberculatus LeConte, 1878) but, even though lengthy, this description lacks good illustrations and does not mention key morphological characters of hydraenid larvae. Recently, several adults of Gymnochthebius jensenhaarupi (Knisch, 1924) were collected in Argentina associ- ated with a number of larvae that can be assigned to this species. This finding offers a good opportunity to describe and figure the larval morphology of Gymnochthebius comparing its morphology with those of other known larvae of Ochthebiinae in order to evaluate their relative position within this subfamily.

\section{MATERIAL AND METHODS}

\section{Material examined}

Twenty-one larvae (eight first instars, eight second instars and five third instars) from Argentina, La Rioja, Talampaya National Park, Shimpa River; 14.v.1999; leg. M. Archangelsky.

The larvae described below were collected with adults of $G$. jensenhaarupi and identified as such by association. All the studied specimens seem to belong to the same species considering their similar external morphology and congruent chaetotaxic pattern. Furthermore, no other species of Hydraenidae was collected in the same locality during the sampling period. Additional adults and larvae were collected in the same locality on 2.xi.1999 (three different stations) and 9.ii.2000 (one station). Adults of $G$. jensenhaarupi were also collected at the same locality on 3.viii.1999.

All larvae were preserved temporarily in glycerol, which allowed for their examination from various perspectives. Afterwards the preparations were transferred into ethanol for two hours for glycerine removal, and then transferred onto permanent DPX slides. All preparations were stained with Chlorazol Black. Drawings were made with a camera lucida attached to a compound microscope. The terminology and format used in the description of these larvae follows that of Delgado \& Soler (1997b) and Delgado \& Palma (1998). The specimens used in this study are deposited in the research collection of the former author held at the Departamento de Zoología y Antropología Física, Facultad de Biología, Universidad de Murcia; additional specimens are deposited in the research collection of M. Archangelsky, at the Universidad Nacional de La Patagonia. 

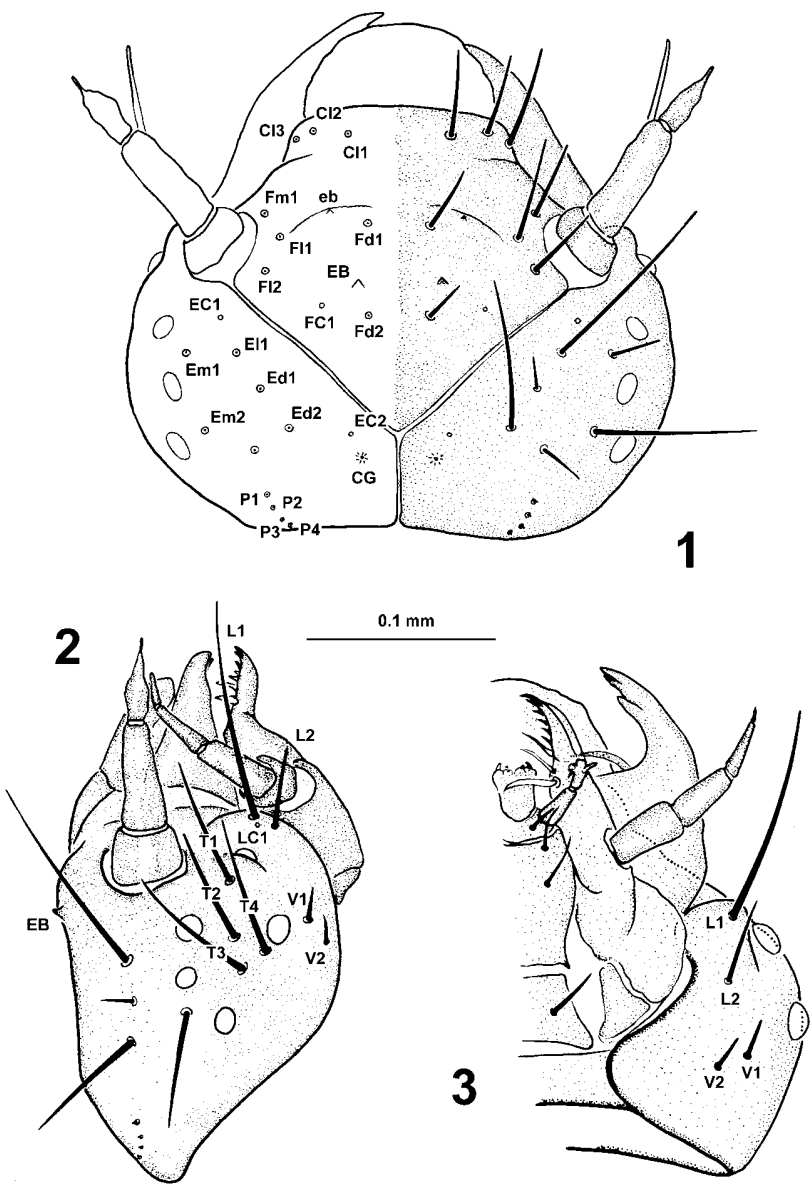

Figs 1-3. First instar larva of $G$. jensenhaarupi, head capsule. 1, dorsal view; 2, lateral view; 3, ventral view. Abbreviations: CG, cephalic glands; Cl1-3, clypeal setae; EB and eb, eggbursters; EC1-2, epicranial campaniform sensilla; Ed1-2, epicranial discal setae; El1-2, epicranial lateral setae; Em1-2, epicranial marginal setae; FC1, frontal campaniform sensillum; Fd1-2, frontal discal setae; F11-2, frontolateral setae; Fm1, frontomarginal setae; L1-2, cephalic lateral setae; LC1, cephalic lateral campaniform sensillum; P1-4, epicranial posterior setae; T1-4, temporal setae; V1-2, ventral setae.

\section{LARVAE OF GYMNOCHTHEBIUS JENSENHAARUPI (Knisch, 1924)}

(Figs 1-22)

\section{First instar}

Elongate, slender. Head and body sclerites moderately sclerotized. Colour of sclerites uniformly yellowish. Total body length about $1.2 \mathrm{~mm}$.

Head

Head capsule width $0.29 \mathrm{~mm} \pm 0.05$ (mean \pm S.D.; $\mathrm{n}=$ 6); head transverse, approximately ovoid in silhouette, slightly narrowed posteriorly and subglobular laterally. Ecdysial line Y-shaped; five stemmata are present on each side, ocular area subdivided into two oblique rows. Chaetotaxy of head capsule as in Figs 1-3. Frontal region (Fig. 1) on each side with five setae, two frontodorsal (Fd1, Fd2), two frontolateral (F11, F12), one frontomarginal (Fm1). Campaniform sensillum (FC1) present and clearly visible in all specimens. Egg-bursters extremely
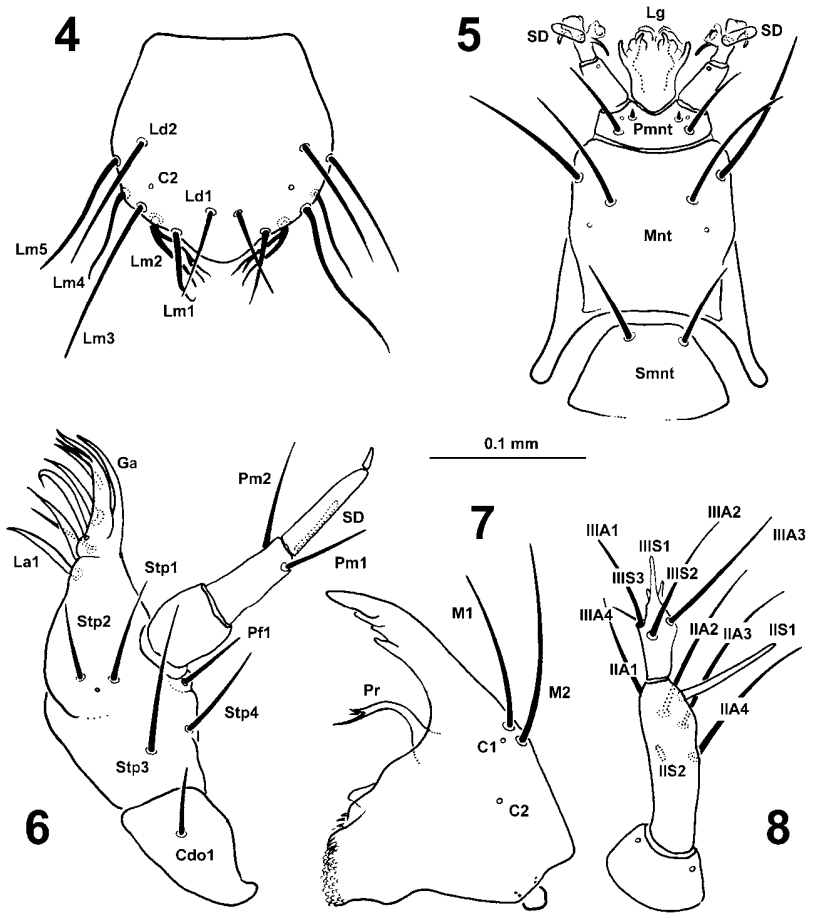

Figs 4-8. First instar larva of $G$. jensenhaarupi, mouthparts and antenna. 4. dorsal view of labrum; 5 , ventral view of labium; 6, ventral view of left maxilla; 7 , dorsal view of right mandible; 8 dorsal view of right antenna. Abbreviations: C1-2: campaniform sensilla; Ga: galea; La1: lacinial seta 1; Lg, ligula; Lm1-5, labral marginal setae; M1-2, mandibular setae; Mnt, mentum; Pf1, palpiferal seta; Pmnt, prementum; Pr, prostheca; SD, sensory digitiform sensilla; Smnt, submentum; Stp1-4, setae of the stipes; IIA1-4, antennal setae of segment II; IIIA1-4, antennal setae of segment III; IIS1-2, antennal solenidia of segment II; IIIS1-3, antennal solenidia of segment III.

reduced and composed by four small denticles, an anterior pair (Fig. 1: eb) not clearly detected in all specimens and a posterior pair (Fig. 1: EB) slightly conspicuous. Frontoclypeal suture indistinct. Clypeus (Fig. 1) with three setae on each side $(\mathrm{Cl1}-\mathrm{Cl} 3)$. Epicranial regions (Fig. 1) each with two campaniform sensilla (EC1, EC2), one cephalic gland (CG) and ten setae: a row of four minute posterior setae (P1-P4), two epicranial dorsal setae (Ed1, Ed2), two epicranial lateral setae (E11, El2) and two epicranial marginal setae (Em1, Em2). Temporal regions (Fig. 2), each with four long setae (T1-T4). Lateral regions (Fig. 2), each with one campaniform sensillum (LC1) and two setae (L1, L2). Ventral regions (Figs 2-3), each with two setae (V1, V2); gula wider than long. Labrum cordiform (Fig. 4) with the basic pattern of chaetotaxy of other hydraenid species (e.g. Delgado \& Palma, 1998), with two campaniform sensilla (C1, C2) on each side and seven setae arranged in two rows: two discal setae (Ld1, Ld2) and five marginal setae (Lm1-Lm5); campaniform sensilla (C1) inconspicuous in most specimens studied; setae Lm1, Lm3 and Lm5 situated dorsolaterally, Lm2 and Lm4 ventrolaterally (Fig. 4); setae Lm2 (Fig. 4) pectinate. Antennae (Fig. 8) 0.4 as long as head capsule width, antennomere II about $3 \times$ as long as antennomere I, with four setae (IIA1-IIA4) and 


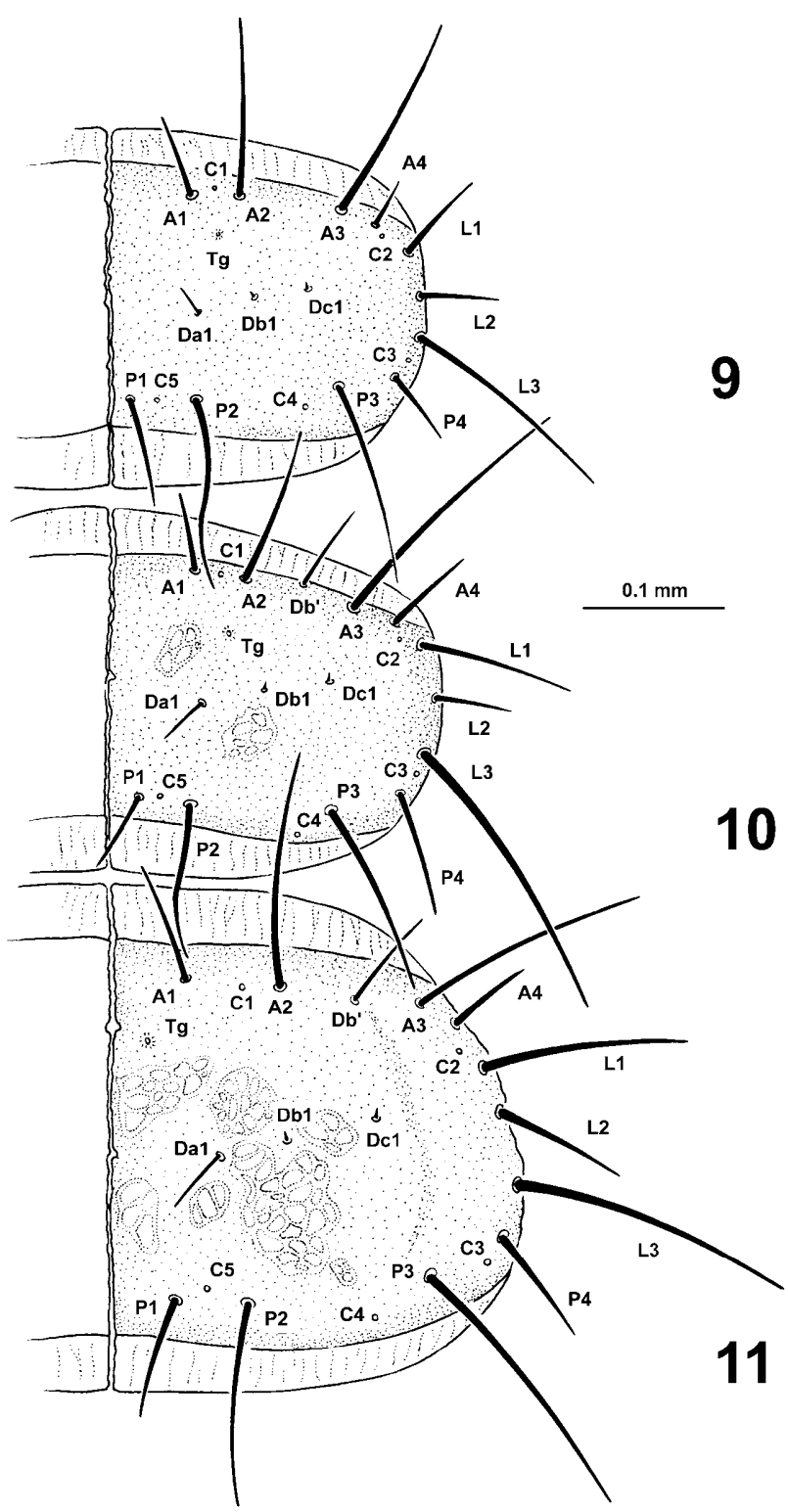

Figs 9-11. Larva of $G$. jensenhaarupi, chaetotaxy of prothorax. 9, first instar; 10. second instar; 11, third instar. Abbreviations: A1-4, anterior setae; C1-5, campaniform sensilla; Da1, $\mathrm{Db} 1, \mathrm{Dc} 1$, primary dorsal discal setae; Db', subprimary dorsal discal setae; L1-3, lateral setae; P1-4, posterior setae; Tg, tergal gland.

two solenidia (IIS1 and IIS2); solenidium IIS1 long, slender, situated on distal end; solenidium IIS2 shorter, positioned ventrally on centre of antennomere; antennomere III $0.7 \times$ as long as II, with four setae (IIIA1-IIIA4) and three apical solenidia (IIIS1-IIIS3); IIIS1 longer than IIIS2 \& IIIS3. Mandibles (Fig. 7) similar in size and shape, with multidentate apex; mesal surface of mandibular base with mola tuberculate, associated with the mola there are two premolar teeth; molar base without penicillus; ventral part of mandibular base with a rounded condyle and without accessory process; both mandibles with a slender curved prostheca ( $\mathrm{Pr}$ ) ending in two or three small teeth; outer edge with two setae. Ventral mouthparts retracted. Maxillae as in Fig. 6: cardines
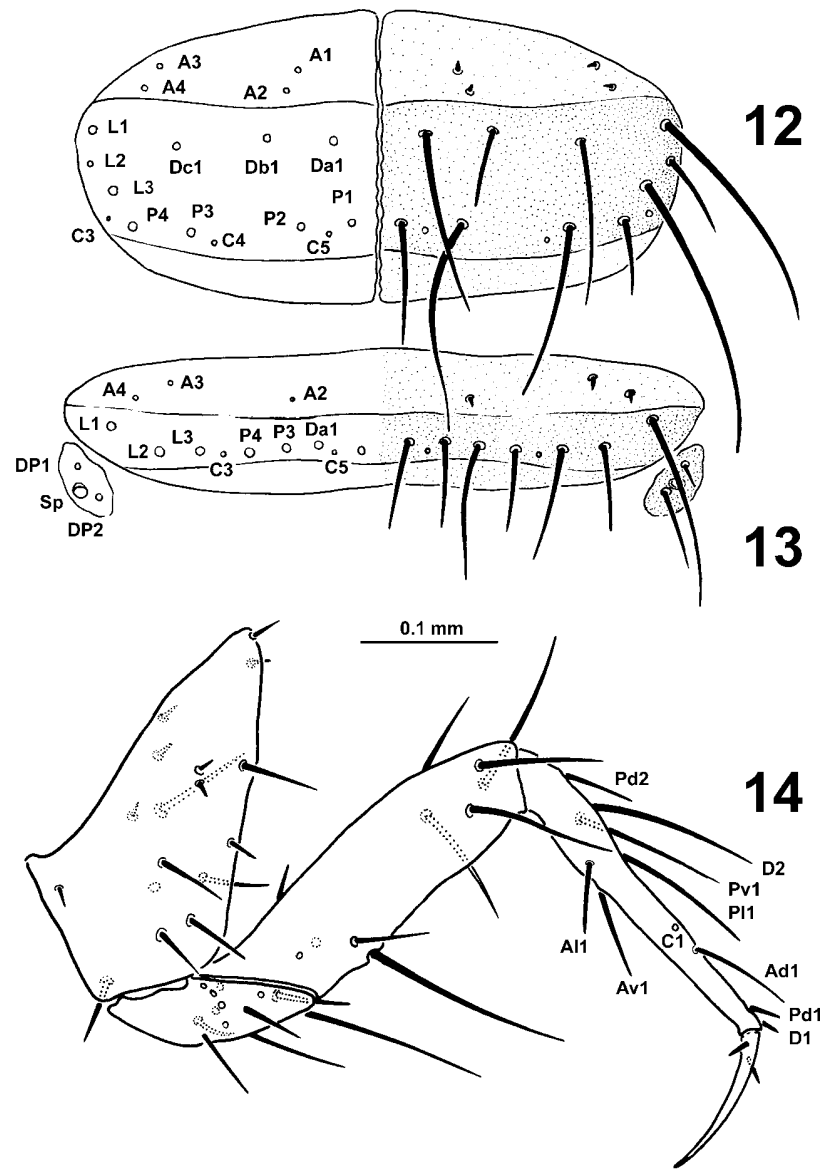

Figs 12-14. Larva of $G$. jensenhaarupi. 12, first instar, mesonotum; 13, first instar, abdominal tergum II; 14, third instar, proleg with labeled chaetotaxy in tibia and tarsungulus. Abbreviations: A1-4, anterior setae; Ad1, anterodorsal seta; A11, anterolateral seta; Av1, anteroventral seta; C1-4, campaniform sensilla; Da1, Db1, Dc1, primary dorsal discal setae; DP1-2, dorsopleural setae; L1-3, lateral setae; P1-4, posterior setae; Pd1-2, posterodorsal setae; P11, posterolateral seta; Pv1, posteroventral seta; Sp, spiracle.

longer than wide, transverse and widely separated from each other by submentum, each with one seta (Cdo1); stipes longer than wide, with four setae (Stp1-Stp4) and one campaniform sensillum; palpifer with a small clearly defined sclerite, and with one seta (Pf1); both galea and lacinia fixed; galea $(\mathrm{Ga})$ hyaline, falciform and slender; lacinia slightly wider than galea, with six setae along outer edge; maxillary palp three-segmented: segment 1 with two campaniform sensilla, segment 2 with two setae (Pm1, Pm2), segment 3 with a long, digitiform, sensorial appendage on external surface (SD), and a small, complex sensorial structure on its apex. Labium (Fig. 5) consisting of three sclerites: submentum (Smnt) with two setae, mentum (Mnt) with four setae and two campaniform sensilla, and prementum (Pmnt) with four setae as well as two inconspicuous campaniform sensilla; ligula (Lg) bearing a number of small apical sensilla; labial palps, each with a cupuliform sensillum bearing several small papillae and pores and a digitiform sensillum. Internal skeletal structures: dorsal endocarinae absent; 

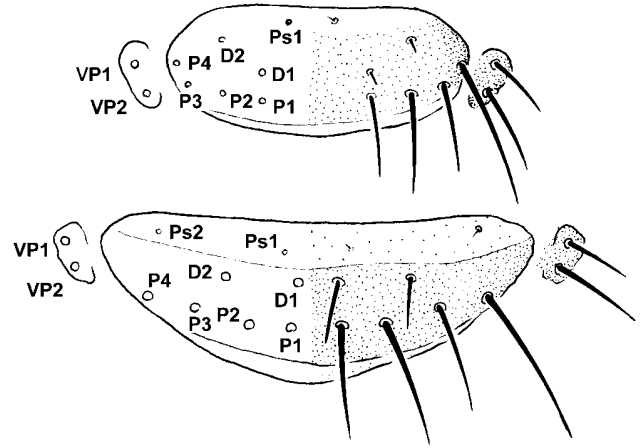

16

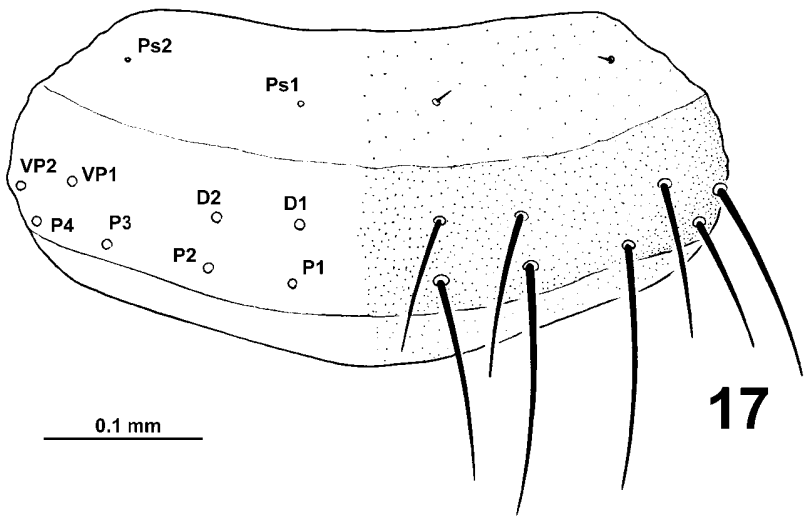

Figs 15-17, Larva of $G$. jensenhaarupi, chaetotaxy of sternites I-VIII. 15, first instar; 16, second instar; 17, third instar. Abbreviations: D1-2, sternal discal setae; P1-4, posterior setae; PS1-2, presternal setae; VP1-2, ventro-pleural setae.

epistomal ridge moderately developed near the dorsal mandibular articulations; posterior arms of tentorium widely separated by the gula; dorsal arms short; tentorial bridge moderately narrow; anterior arms well developed.

Thorax

Thoracic terga each with a large, well-developed sclerite; thoracic pleura and sterna consisting of several small sclerotized plates with the basic pattern of chaetotaxy of other ochthebiine species (see Delgado \& Soler, 1997b). Prothorax slightly larger than meso- and metathorax. Pronotum (Fig. 9) with fourteen setae and five campaniform sensilla on each side. Setae: four in anterior row A (A1-A4), A1 and A4 shorter; three in lateral row L (L1-L3), L2 shortest; four in posterior row P (P1-P4), P1 and $\mathrm{P} 4$ shorter; one in each of the three discal groups (Da1, Db1, Dc1), Da1 short and slender, Db1 and Dc1 minute. Pronotal campaniform sensilla $\mathrm{C} 1$ to $\mathrm{C} 5$ present. One tergal gland (Tg) on each side of pronotum. Mesonotum (Fig. 12) with fourteen setae and three campaniform sensilla (C3-5) on each side. Setae: four minute setae in anterior row A (A1-A4); three longer setae in lateral row L (L1-L3), L2 shortest; four in posterior row $\mathrm{P}$ (P1-P4); one in each of the three discal groups (Da1, $\mathrm{Db} 1, \mathrm{Dc} 1)$; in mesonotum discal setae not reduced. Mesonotal campaniform sensilla $\mathrm{C} 1$ and $\mathrm{C} 2$ absent. In addition, two inconspicuous tergal glands (TG) near anterior margin of the mesonotum. Metanotum similar to mesonotum. Legs (Fig. 14) very elongate, especially tarsungulus, with typical chaetotaxy found in other

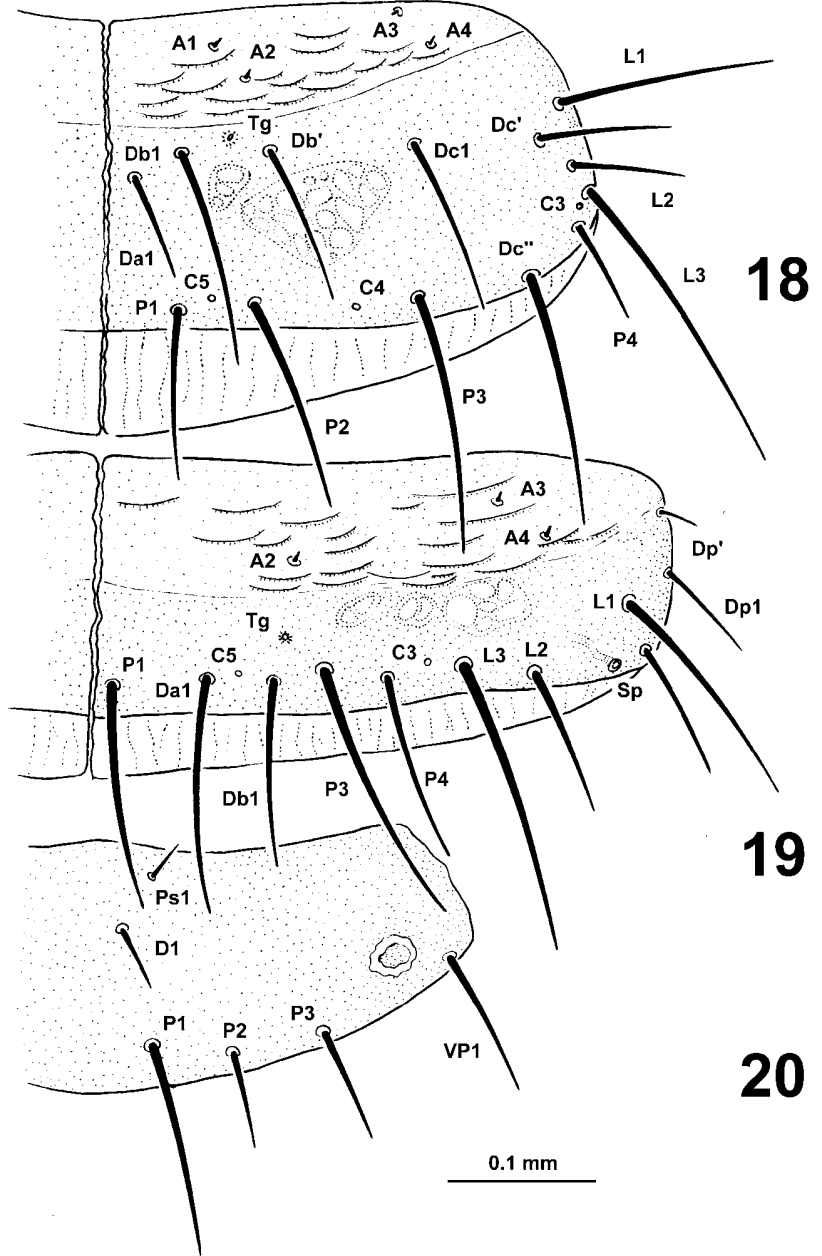

Figs 18-20. Third instar larva of G. jensenhaarupi. 18, mesonotum; 19, abdominal tergum II; 20, abdominal sternum I. Abbreviations: A1-4, anterior setae; C3-5, campaniform sensilla; D1, sternal discal seta; Da1, Db1, Dc1, primary dorsal discal setae; Db', Dc', Dc', subprimary dorsal discal setae; DP1-2, dorsopleural setae, DP', dorsopleural subprimary seta; L1-3, lateral setae; P1-4, posterior setae; Ps1, presternal seta; Sp, spiracle; Tg, tergal gland.

hydraenid larvae (Delgado \& Soler, 1997c), seta Ad1 present and long. Circular annular spiracles on mesothorax located on lateral short tubercles.

\section{Abdomen}

Abdomen subcylindrical in cross-section, straight to slightly curved ventrally and tapering posteriorly. Abdominal terga and sterna I-VIII each with a well sclerotized plate; abdominal pleura with two small sclerites: a dorsopleural and a ventropleural sclerite on each side. Tergites I-VIII as in Fig. 13. Number of setae and campaniform sensilla reduced: setae A1, Db1, Dc1, P2 and sensilla $\mathrm{C} 1, \mathrm{C} 2, \mathrm{C} 4$ absent. Remaining setae are arranged in a transverse row. Dorsopleural sclerites of abdominal segment I, with a circular annular spiracle and one seta (DP1). Dorsopleural sclerites of segments II to VIII (Fig. 13), each with a spiracle (SP) of the same kind to that of segment I and two setae (DP1, DP2). Ventropleural sclerites of segment I each with one seta: VP1. 


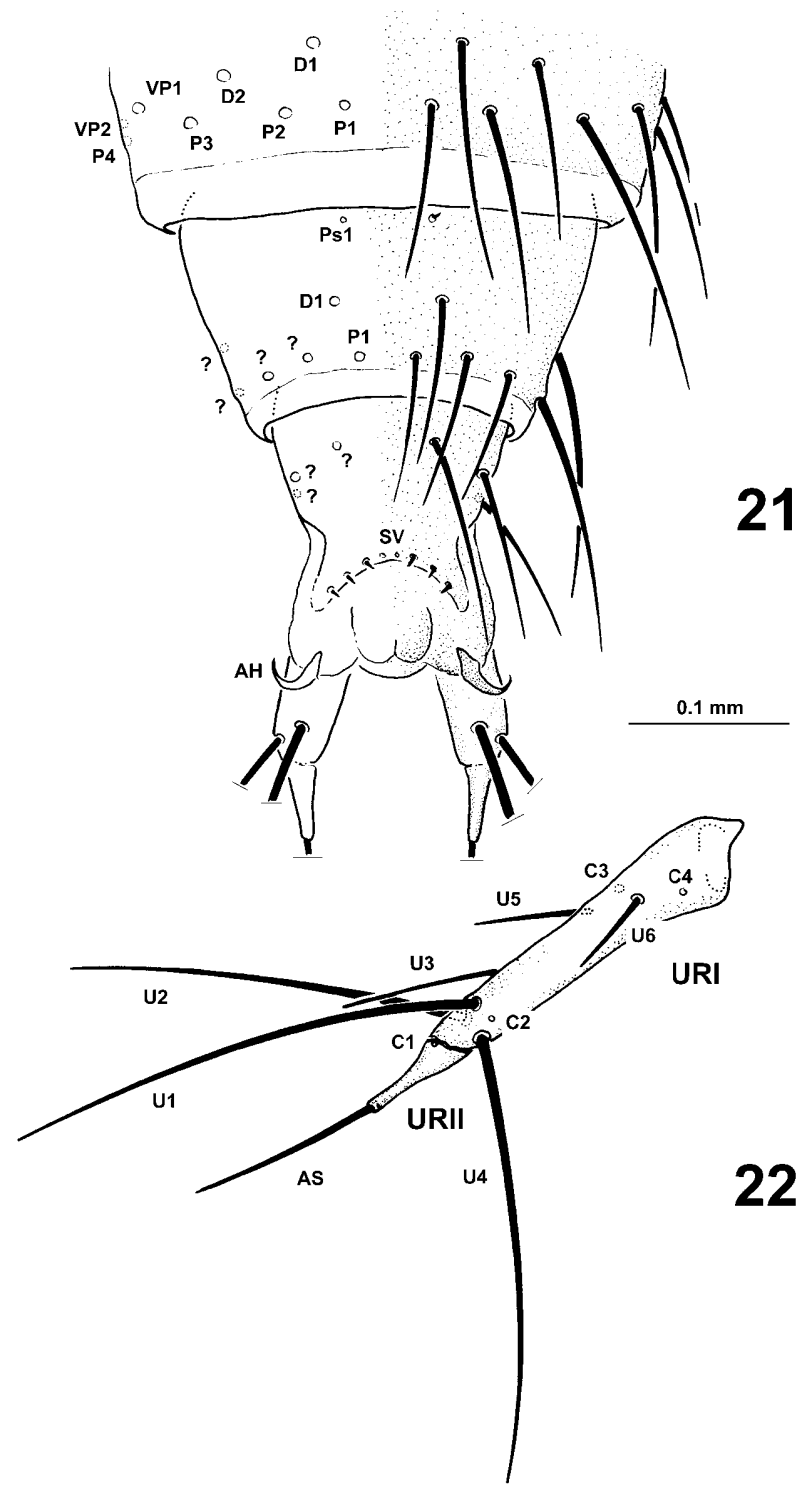

Figs 21-22. Third instar larva of G. jensenhaarupi; 21, ventral view of abdominal segments VIII-X; 22, left urogomphus, dorsal view. Abbreviations: AH, anal hooks; AS, apical seta; C1-4, campaniform sensilla; D1-2, sternal discal setae; P1-4, posterior setae; Ps1, presternal seta; SV, spine-like ventral setae; U1-6, urogomphal setae; URI-II, urogomphal segments; VP1-2, ventro-pleural setae; ?, setae of unknown homology.

Ventropleural sclerites of segments II to VIII (Fig. 15) each with two setae (VP1, VP2). Sternite I (see Fig. 20) with five setae on each side: one small presternal seta (PS1), one discal seta (D1), and three posterior setae (P1 to P3). Sternites II-VIII as in Fig. 15, similar to sternite I but with two additional setae (D2 and P4). Segment IX bearing a pair of urogomphi, without dorsopleural nor ventropleural sclerites and with reduced chaetotaxy. Urogomphi (Fig. 22) two-segmented: segment I (URI) mobile, not fused to tergite IX, with six setae (U1-U6) and four campaniform sensilla ( $1-\mathrm{C} 4)$, seta U6 far from base of urogomphus; segment II (URII) $0.25 \times$ as long as segment I, with an apical seta (AS). Abdominal segment $\mathrm{X}$ as that shown in Fig. 21, but smaller since this figure

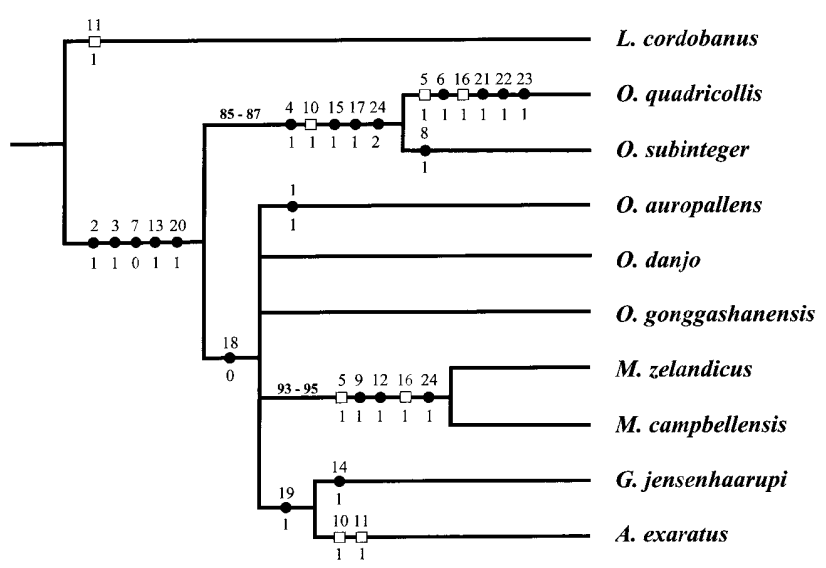

Fig. 23. Provisional phylogeny of known Ochthebiinae larvae. Character state changes are superimposed onto the cladogram; black circles = synapomorphies; white squares = homoplasies (independent gains). The upper bold numbers on some branches represent the range of jackknife values.

refers to a third instar larva, forming a completely sclerotized ring, with three long ventrolateral setae of unknown homology and three spine-like ventral setae (SV) on each side. Anal lobes (Fig. 21) moderately developed, each with one anal hook $(\mathrm{AH})$, frequently retracted.

\section{Second instar}

Total body length about $1.6 \mathrm{~mm}$.

Head

Head capsule width: $0.34 \mathrm{~mm} \pm 0.06$ (mean \pm S.D.; $\mathrm{n}=$ 7). Similar to that of first instar larvae but lacking cephalic egg-bursters. Additional subprimary and secondary setae absent.

Thorax

Pronotum as in first instar, with one additional subprimary seta on each side (Fig. 10); according to their position these setae should be considered as Db'. Subprimary setae Da', Da", Db', Dc' and Dc', absent. Mesoand metanotum similar in shape to those of first instar, with three pairs of additional subprimary setae: Db', Dc' and Dc'.

\section{Abdomen}

Abdominal dorsopleural sclerites I to VIII with a pair of additional subprimary setae (DP'). Abdominal ventropleural sclerites and sternites (Fig. 16) without additional subprimary setae. Dorsopleural sclerites not fused to their respective tergites. Shape and chaetotaxy of segments IX and $\mathrm{X}$ as in first instar larvae.

\section{Third instar}

Total body length about $2.4 \mathrm{~mm}$.

Head

Head capsule width: $0.45 \mathrm{~mm} \pm 0.02$ (mean \pm S.D.; $\mathrm{n}=$ 3 ). Chaetotaxy as that of first and second instars. Additional subprimary and secondary setae absent. 


\section{Thorax}

Pronotum and mesonotum as in Figs 11 and 18, respectively. Chaetotaxy as that of second instar larvae.

\section{Abdomen}

Besides an obvious size increase, the single morphological distinction of third instar larvae is in segments I to IV in which the dorso- and ventropleural sclerites are fused to their respective tergites and sternites (Figs 19 and 20). Consequentially, the chaetotaxy of the dorsolateral plates is the addition of the setae from the tergites plus those from the dorsopleural sclerites, while the chaetotaxy of the ventrolateral plates is the addition of the setae from the sternites plus those from the ventropleural sclerites. Setae DP1, DP2, DP' and spiracle placed on lateral margins of dorsolateral plate; setae VP1 (abdominal segment I) and VP2 (all abdominal segments) placed on lateral margins of lateroventral plate (Figs 17 and 20). Shape and chaetotaxy of segments IX and X (Fig. 21) as that of first and second instars.

\section{Habitat}

The larvae were found associated to filamentous algae growing on the margins of small montane creeks, in areas where the water flow was slow.

\section{Morphological remarks and comparative notes}

The larva of $G$. jensenhaarupi resembles those ochthebiine larvae with well developed anal hooks, namely all the described larvae of Ochthebius s. str. as well as the larva of Aulacochthebius exaratus (Mulsant, 1844). Compared with these larvae, G. jensenhaarupi can be recognized by the elongation of some structures and appendages such as the solenidium IIS1 of antennomere II, maxillary palpomeres, legs (especially distal segments) and urogomphi. However, these general features are not useful enough to clearly distinguish among these larvae with certainty. More informative is the shape of the cephalic egg-bursters in first instar larvae. Gymnochthebius jensenhaarupi differs from all described ochthebiine larvae by the strong reduction of these cuticular structures. Richmond (1920) reared and described first instar larvae of G. fossatus, and in his description there is no reference to the presence of egg-bursters. We believe that these structures may have been overlooked by Richmond (1920) due to their minute size, and that this trait is probably a synapomorphy with other larvae of the genus Gymnochthebius.

Besides this feature, only useful in first instar larvae, $G$. jensenhaarupi can only be distinguished with certainty from the other described Ochthebiinae larvae using pore and chaetotaxic traits. Gymnochthebius jensenhaarupi differs by the strong reduction of prothoracic discal setae Db1 and Dc1 (Figs 9-11) and by the presence of abdominal sternal setae P4 on segments II to VIII (Figs 15-17). The minute prothoracic setae Db1 and Dc1 are the most evident diagnostic characters for this species. Gymnochthebius fossatus has well developed prothoracic discal setae in rows $\mathrm{Da}, \mathrm{Db}$ and Dc, described as "median transverse row of setae" by Richmond (1920: see text and Plate III, Fig. 12).

\section{CLADISTIC ANALYSIS}

In order to examine the relationships between $G$. jensenhaarupi and eight other ochthebiine taxa with thoroughly described preimaginal stages (Delgado, 2003; Delgado \& Matsui, 2000; Delgado \& Palma, 1998; Delgado \& Soler, 1996a, 1997a,b; Delgado et al., 1998), a number of larval features were analyzed phylogenetically. Cladograms were generated using Hennig86 vers. 1.5 (Farris, 1988), applying the implicit enumeration option (ie*) for tree calculation. Winclada vers. 0.9.9 (Nixon, 1999) was used to display the additive binary characters on the obtained cladogram. The matrix was also analyzed with PAUP*b10 (Macintosh version; Swofford, 2002). Jackknife analyses with 200 replicates (50\% resample) were performed to measure clade support.

The character matrix analyzed (Table 1) includes 23 binary characters and one multistate character (24), which was treated as non-additive (unordered). The absence of information is represented by a question mark (?) in Table 1. The larva of Limnebius cordobanus d'Orchymont, 1938 (Delgado \& Soler, 1997c) was used as the outgroup. Since the monophyly of the ingroup is not in doubt (Beutel et al., 2003, Perkins, 1997) we used only one outgroup. However, several character comparisons were made with the larvae of Hydraena hernandoi Fresneda \&

TABLE 1. Character matrix of larval morphological characters for Ochthebiinae and the outgroup (Limnebius cordobanus).

\begin{tabular}{|c|c|}
\hline Species & \begin{tabular}{llllllllllllllllllllllll}
\multicolumn{1}{c}{ Transformation series } \\
0 & 0 & 0 & 0 & 0 & 0 & 0 & 0 & 0 & 1 & 1 & 1 & 1 & 1 & 1 & 1 & 1 & 1 & 1 & 2 & 2 & 2 & 2 & 2 \\
1 & 2 & 3 & 4 & 5 & 6 & 7 & 8 & 9 & 0 & 1 & 2 & 3 & 4 & 5 & 6 & 7 & 8 & 9 & 0 & 1 & 2 & 3 & 4
\end{tabular} \\
\hline Limnebius cordobanus & 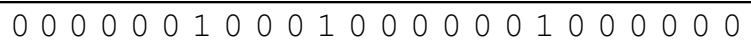 \\
\hline Ochthebius auropallens & 1110000000000001000000010100000 \\
\hline Ochthebius danjo & 011000000000000100000001010000 \\
\hline Ochthebius gonggashanensis & $0 ? \begin{array}{llllllllllllllllllllll}0 & 0 & 0 & 0 & 0 & 0 & 0 & 0 & 0 & 0 & 1 & 0 & 0 & 0 & 0 & 0 & 0 & 1 & 0 & 0 & 0 & 0\end{array}$ \\
\hline Ochthebius quadricollis & 01111110000100101011111011110 \\
\hline Ochthebius subinteger & 0111000010100010101101010002 \\
\hline Gymnochthebius jensenhaarupi & 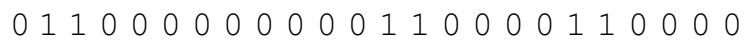 \\
\hline Meropathus zelandicus & 0110100010011001000101001 \\
\hline Meropathus campbellensis & 01101000100110010001001 \\
\hline Aulacochthebius exaratus & 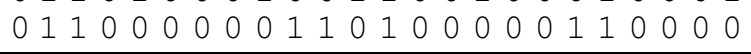 \\
\hline
\end{tabular}

For description of characters see text. Insuficient data available are coded as “?”. 
Lagar, 1990 (Delgado \& Soler, 1996b) and Podaena latipalpis Ordish, 1984 (Delgado \& Palma, 2004). In a few cases, comparisons were also made using published information from larvae of the putative sister-group of Hydraenidae, the family Ptiliidae (Dybas, 1976; Grebennikov \& Beutel, 2002).

Character 1. Number of cephalic glands. Two states. (0) one pair; (1) two pairs. Within Hydraenidae two distinct conditions occur with regard to the number of cephalic glands. Most known larvae present only one pair of well developed cephalic glands, including Limnebius (Delgado \& Soler, 1997c) and most Ochthebiinae, except for Ochthebius auropallens Fairmaire, 1879 Delgado \& Soler (1997b). CI = 1 .

Character 2. Cephalic egg-bursters in the first instar larva. Two states. (0) absent; (1) present. Cephalic eggbursters are found only in the first-instar larvae of Ochthebiinae. Cephalic eggs-bursters are absent in Limnebius (Delgado \& Soler, 1997c), Hydraena (Delgado \& Soler, 1996b), Podaena (Delgado \& Palma, 2004) and Ptiliidae (Grebennikov \& Beutel, 2002). CI $=1$.

Character 3. Number of apical solenidia on antennomere II. Two states. (0) two; (1) one. Larvae of Limnebius have two apical solenidia on antennomere II (Delgado \& Soler, 1997c). These are also found in the larvae of Hydraena (Delgado \& Soler, 1996b) and Podaena (Delgado \& Palma, 2004). Gymnochthebius as well as the other known ochthebiine larvae have a single apical solenidium in antennomere II. $\mathrm{CI}=1$.

Character 4. Mandibular penicillum. Two states. (0) absent; (1) present. In larvae of Limnebius (Delgado \& Soler, 1997c) a mandibular penicillum is absent. Among Ochthebiinae larvae this feature has been described only for Ochthebius quadricollis Mulsant, 1844 and Ochthebius subinteger Mulsant \& Rey, 1861. CI = 1.

Character 5. Shape of ligula. Two states. (0) digitate; (1) globose. A labium with digitate ligula is present in most known larvae of Ochthebiinae and also in Limnebius (Delgado \& Soler, 1997c). A globose, well developed ligula lacking apical digitate structures, is only known so far in a few larvae within the subfamily Ochthebiinae: $O$. quadricollis (Delgado \& Soler, 1997a) and Meropathus Enderlein, 1901 (Delgado \& Palma, 1998). CI =0.5.

Character 6. Labral marginal setae Lm1. Two states. (0) Lm1 of normal shape; (1) pectinate. The pectinate Lm1 seems to be an autapomorphy of $O$. quadricollis (Delgado $\&$ Soler, 1997a). CI = 1 .

Character 7. Length of antennal solenidium IIIS3. Two states. (0) short, similar in length to solenidia IIIS1 and IIIS2; (1) long, much longer than solenidia IIIS1 and IIIS2. Three distal solenidia on antennal segment III are typical in larvae of Staphylinoidea. They are of similar length in Ptiliidae (Dybas, 1976). The same condition can be observed in larvae of Ochthebiinae (Delgado \& Soler, 1997b; Delgado et al., 1998). However, in larvae of Limnebius (Delgado \& Soler, 1997c) the antennal solenidium IIIS 3 is longer than both IIIS 1 and IIIS2. CI $=1$.

Character 8. Cephalic temporal setae T2. Two states. (0) present; (1) absent. Loss of T2 in the cephalic capsule of O. subinteger (Delgado \& Soler, 1996a) should be considered at present as an autapomorphy for this species. $\mathrm{CI}=1$.

Character 9. Frontal campaniform sensilla FC1. Two states. (0) present; (1) absent. Loss of FC1 in the frontal region of Meropathus (Delgado \& Palma, 1998) should be considered at present as an autapomorphy for this genus. $\mathrm{CI}=1$.

Character 10. Cephalic ventral setae V2. Two states. (0) present; (1) absent. A pair of ventral setae (V1 and V2) is present on each side of the cephalic capsule of Limnebius larvae (Delgado \& Soler, 1997c) and in several larvae of Ochthebiinae. The larvae of $O$. quadricollis, O. subinteger and $A$. exaratus have only a single ventral seta on each side of the head capsule. $\mathrm{CI}=0.5$.

Character 11. Thoracic campaniform sensilla C4. Two states. (0) present; (1) absent. Campaniform sensilla C4 are present in Podaena (Delgado \& Palma, 2004) as well as in almost all known larvae of Ochthebiinae, except $A$. exaratus (Delgado et al., 1998). C4 also appears to be present in Ptiliidae (see Grebennikov \& Beutel, 2002: Fig. 3 campaniform sensilla $F$ and $G$ ). Thoracic sensilla C4 are absent in Limnebius (Delgado \& Soler, 1997c) and Hydraena (Delgado \& Soler, 1996b). CI =0.5.

Character 12. Additional prothoracic campaniform sensilla C'. Two states. (0) absent; (1) present. The presence of two additional campaniform sensilla on the pronotum in the three known species of Meropathus is a unique trait that should be considered an autapomorphy for this genus (Delgado \& Palma, 1998). CI $=1$.

Character 13. Number of thoracic tergal glands. Two states. (0) two pairs; (1) one pair. Two pairs of welldeveloped tergal glands are found in larvae of Limnebius (Delgado \& Soler, 1997c). All the known larvae of Ochthebiinae have a single pair of tergal glands. $\mathrm{CI}=1$.

Character 14. Length of pronotal setae Db1 and Dc1. Two states. (0) usual length, setiform; (1) extremely reduced, minute. The presence of minute setae Db1 and Dc1 seems to be an autapomorphy for $G$. jensenhaarupi (Figs 7-9). CI = 1 .

Character 15. Tibiotarsal setae Ad1. Two states. (0) present; (1) absent. The tibiotarsal setae Ad1 are present in Limnebius (Delgado \& Soler, 1997c) as well as in a great part of the species of Ochthebiinae. Setae Ad1 are absent on the legs of O. quadricollis (Delgado \& Soler, 1997a) and O. subinteger (Delgado \& Soler, 1996a). CI = 1.

Character 16. Subprimary abdominal setae DP'. Two states. (0) present; (1) absent. The subprimary dorsopleural setae DP' are present in the second and third instars larvae of Linmebius (Delgado \& Soler, 1997c) as well as in most larvae of the subfamily Ochthebiinae, except O. quadricollis (Delgado \& Soler, 1997a) and Meropathus (Delgado \& Palma, 1998). CI $=0.5$.

Character 17. Abdominal sternal setae D1. Two states. (0) present; (1) absent. The abdominal sternal setae D1 are present in Limnebius (Delgado \& Soler, 1997c) as well as in most known Ochthebiinae larvae. Setae D1 are 
absent in O. quadricollis and O. subinteger (Delgado \& Soler, 1996a, 1997a). CI = 1.

Character 18. Abdominal sternal setae D2. Two states. (0) present; (1) absent. These setae D2 are present in Ptiliidae (Delgado, unpubl.). This condition is also found in Podaena (Delgado \& Palma, 2004) as well as in most known Ochthebiinae larvae. However, in Hydraena (Delgado \& Soler, 1997b), Limnebius (Delgado \& Soler, 1997c), O. subinteger (Delgado \& Soler, 1996a) and $O$. quadricollis (Delgado \& Soler, 1997a) D2 are absent. CI $=1$.

Character 19. Abdominal sternal setae P3. Two states. (0) absent; (1) present. The abdominal sternal setae P3 are absent in Limnebius (Delgado \& Soler, 1997c), Hydraena (Delgado \& Soler, 1996b), Podaena (Delgado \& Palma, 2004) as well as in all known Ochthebiinae larvae, with the exception of $A$. exaratus (Delgado et al., 1998) and $G$. jensenhaarupi (Figs 12-14). CI $=1$.

Character 20. Insertion of urogomphi. Two states. (0) urogomphi well separated, with the distance between their bases equal or longer than the mid-width of their basal segment; (1) urogomphi inserted very close to each other, often contiguous. This character was used by Perkins (1980) and Hansen (1996) to distinguish larvae of Ochthebius from those of Hydraena and Limnebius. The first condition (0) is found in Ptiliidae (Dybas, 1976) as well as in Hydraena (Delgado \& Soler, 1996b), Limnebius (Delgado \& Soler, 1997c) and Podaena (Delgado \& Palma, 2004). Contiguous urogomphi can be observed in larvae of Ochthebiinae. $\mathrm{CI}=1$.

Character 21. Pygopodial setae. Two states. (0) present; (1) absent. A row of tiny setae and pores is present at the distal ventral margin of the pygopod or anal vesicle in all known larvae of Limnebius (Delgado \& Soler, 1997c), Hydraena (Delgado \& Soler, 1996b) and Podaena (Delgado \& Palma, 2004) as well as in most Ochthebiinae. Thus far, only O. quadricollis (Delgado \& Soler, 1997a) lacks these setae. $\mathrm{CI}=1$.

Character 22. Urogomphal campaniform sensilla C4. Two states. (0) present; (1) absent. The presence of four urogomphal campaniform sensilla $(\mathrm{C} 1$ to $\mathrm{C} 4)$ can be observed in almost all the known larvae of Hydraenidae. The absence of $\mathrm{C} 4$ seems to be an autapomorphy of $O$. quadricollis (Delgado \& Soler, 1997a). CI $=1$.

Character 23. Length of urogomphal setae U6. Two states. (0) short; (1) long. Urogomphal seta U6 are generally short in Hydraenidae larvae. The presence of a long seta U6 on each urogomphus is considered another autapomorphy of $O$. quadricollis (Delgado \& Soler, 1997a). CI $=1$.

Character 24. Anal hooks. Three non-additive states. (0) well developed; (1) extremely reduced or vestigial; (2) completely absent. Two well developed anal hooks can be observed in the larvae of the family Ptiliidae (Dybas, 1976; Grebennikov \& Beutel, 2002) as well as in Limnebius (Delgado \& Soler, 1997c), Hydraena (Delgado \& Soler, 1996b), Podaena (Delgado \& Palma, 2004) and a great part of the larvae of Ochthebiinae. Larvae of Meropathus have extremely reduced anal hooks. In some spe- cies these structures are present as two vestigial sclerotized scars (Delgado \& Palma, 1998). In O. quadricollis (Delgado \& Soler, 1997a) and O. subinteger (Delgado \& Soler, 1996a) anal hooks are completely absent. CI $=1$.

\section{RESULTS OF THE CLADISTIC ANALYSIS}

Twenty-four morphological characters were used in this phylogenetic analysis as is indicated in Table 1. Several of the characters used are autapomorphies, therefore not informative, but they are included because of their importance as diagnostic characters. The cladistic analysis yielded a single shortest tree (length $29 ; \mathrm{CI}=0.87$; CI excluding uninformative characters $=0.76$; $\mathrm{RI}=0.76$; $\mathrm{RC}$ $=0.659)$, shown in Fig. 23. Monophyletic groups and apomorphies are commented in the following paragraphs.

The subfamily Ochthebiinae is clearly monophyletic, characterized by five autapomorphies: i) presence of cephalic egg-bursters in first instar larvae (character 2); ii) a single solenidium at the distal end of the antennomere II (character 3); iii) short antennal solenidium IIIS3 (character 7); iv) a single pair of thoracic glands (character 13); and v) urogomphi inserted very close to each other (character 20).

Within Ochthebiinae there are two clades in our cladogram. The first clade includes the species $O$. quadricollis and $O$. subinteger, and is reasonably well supported (jackknife values ranging between $85-87$ ). This clade is diagnosed by the presence of five derived states (one homoplastic): i) presence of mandibular penicillum (character 4), ii) cephalic setae V2 absent (also absent in $A$. exaratus, character 10), iii) tibiotarsal setae Ad1 absent (character 15), iv) abdominal sternal setae D1 absent (character 17) and v) anal hooks completely absent (character 24, apomorphic condition 2).

The sister clade of $O$. quadricollis $+O$. subinteger is weakly supported by a single transformation (character 18 ) and is composed by a polytomy of three representatives of the subgenus Ochthebius s. str. (O. auropallens, $O$. danjo Nakane, 1990 and O. gonggashanensis Jäch, 2003), a clade with the two representatives of the genus Meropathus (M. campbellensis Brookes, 1951 and $M$. zelandicus Ordish, 1984) plus a clade with representatives of the genera Gymnochthebius and Aulacochthebius ( $G$. jensenhaarupi and A. exaratus).

The two members of Meropathus form a well supported clade (jackknife values ranging between 93-95), diagnosed by five derived states (two homoplastic): i) ligula globose (character 5), ii) frontal campaniform sensillum FC1 absent (character 9), iii) prothoracic campaniform sensillum C' present (character 12), iv) abdominal tergal seta DP' absent (character 16), and v) anal hooks vestigial (character 24, apomorphic condition 1).

Finally, the clade formed by $G$. jensenhaarupi and $A$. exaratus is weakly supported by a single transformation: presence of abdominal sternal setae P3 (character 19); jackknife values for this clade range between 38-49. 


\section{DISCUSSION}

As stated previously, this analysis represents an attempt to solve the phylogenetic relationships of $G$. jensenhaarupi, as a representative of the genus Gymnochthebius with other species of Ochthebiinae based on larval characters. However, in addition to the main subject of this work, several other points that we find of interest deserve some comments.

Our work provides additional support to the monophyly of the subfamily Ochthebiinae. In this sense, larval morphology is consistent with recent studies based on adult morphology (Beutel et al., 2003; Perkins, 1997).

The close phylogenetic relationship between $O$. quadricollis and $O$. subinteger, two members of the questioned subgenera Calobius Wollaston, 1854 and Cobalius Rey, 1886 of Ochthebius respectively, is another interesting result of this study. The present analysis suggests that members of this clade have accumulated a high number of apomorphic character states during the evolution of the subfamily Ochthebiinae (five larval characters). Both this close relation and their derived placement within Ochthebiinae, has been suggested previously in other studies dealing with both adult (Perkins, 1997; Beutel et al., 2003) and larval morphology (Delgado \& Soler, 1996a). Our results reinforce these ideas, but conflict with the taxonomic status given by Perkins (1997) to these subgenera. Perkins (1997) regarded the clade Calobius + Cobalius as the quadricollis species group, synonymizing Calobius and Cobalius with Ochthebius s. str. in the light of an extensive adult morphological analysis. Hansen (1998) followed this suggestion in the case of Cobalius, but maintained Calobius as a valid subgenus. Recently Beutel et al. (2003) have suggested a separate generic status for Calobius based on several adult head traits. Larval morphology points in this same direction since Ochthebius, as currently composed, seems to be paraphyletic. The five species of Ochthebius studied by us are nested separately within the two main clades of our cladogram. In fact, the non-monophyly of Ochthebius is hardly a surprise since for a long time there has been little compelling evidence for the monophyly of this genus and virtually nothing is known about the relationships among its different subgenera (Hansen, 1991). Our results suggest that at least some species of Calobius and Cobalius could represent a different lineage within Ochthebiinae. Interestingly no synapomorphies for the members of Ochthebius s. str. were found in our analysis. However, in the present study we do not suggest any changes to the current classification of Ochthebiinae since our results are based on the reduced number of taxa presently at hand and this could lead to a spurious conclusion.

The genus Meropathus is depicted in our cladogram as a well supported clade. Larvae of this genus are very distinctive by the absence of campaniform sensilla FC1 and setae DP', as well as by the presence of additional sensilla C'. It is noteworthy that two other characters observed in these larvae: presence of a globose ligula and a strong reduction of anal hooks (characters 5 and 24), seem to have evolved at least twice during the evolution of the
Ochthebiinae (Fig. 23), once in Meropathus, and once in the clade $O$. quadricollis $+O$. subinteger.

As we have pointed out in the introduction, Gymnochthebius was proposed to be closely related to Aulacochthebius by Hansen (1991) and, especially by Perkins (1997) who based this phylogenetic relationship on the similar shape of some aedeagal and abdominal structures of the adults. The cladogram produced in the present work supports this close relationship with larval characters, adding a new putative synapomorphy: the presence of abdominal sternal seta P3 in the larvae of these two genera. Unfortunately, this study failed to discover more synapomorphic features between these larvae. However, our results suggest that larval chaetotaxic traits offer valuable information, which can be used to critically appraise the current classification and phylogenetic relationships of Hydraenidae. Evidently, future studies should include more taxa, improving progressively our knowledge about the phylogenetic relationships of this interesting group of water beetles.

ACKNOWLEGDEMENTS. We are indebted to M. Fikáček, Charles University and an anonymous referee for valuable comments on the manuscript. We thank CONICET (National Research Council) and Dirección de Parques Nacionales (Argentina). Fieldwork was partially supported by the grant PIP 0568/98 (CONICET) for biodiversity studies in the National Park Talampaya.

\section{REFERENCES}

Beutel R.G., Anton E. \& JÄCH M.A. 2003: On the evolution of adult head structures and the phylogeny of Hydraenidae (Coleoptera, Staphyliniformia). J. Zool. Syst. Evol. Res. 41(4): 256-275.

Delgado J.A. 2003: Hydraenidae: III. Description of the third instar larva of Ochthebius (s. str.) gonggashanensis Jäch (Coleoptera). In Jäch M.A. \& Ji L. (eds): Water Beetles of China. Vol. III. Zoologisch-Botanische Gesllschaft in Österreich and Wiener Coleopterologenverein, Wien, pp. 371-377.

Delgado J.A. \& Matsui E. 2000: Description of the larval stages of Ochthebius (s. str.) danjo Nakane (Coleoptera: Hydraenidae) from Japan. Entomol. Sci. 3(1): 125-130.

Delgado J.A. \& Palma R.L. 1998: Larval stages of three Meropathus species (Coleoptera: Hydraenidae: Ochthebiinae) from New Zealand. New Zeal. J. Zool. 25: 409-419.

Delgado J.A. \& Palma R.L. 2004: Larval stages of Podaena latipalpis from New Zealand and phylogenetic relationships of the subfamily Orchymontiinae based on larval characters (Insecta: Coleoptera: Hydraenidae). New Zeal. J. Zool. 31: 327-242.

Delgado J.A. \& Soler A.G. 1996a: Descripción de la larva de Ochthebius (Cobalius) subinteger Mulsant \& Rey, 1861 (Coleoptera, Hydraenidae). Graellsia 51: 121-128.

Delgado J.A. \& Soler A.G. 1996b: Morphology and chaetotaxy of the first-instar larva of Hydraena (Phothydraena) hernandoi Fresneda \& Lagar (Coleoptera: Hydraenidae). Koleopt. Rdsch. 66: 147-154.

Delgado J.A. \& Soler A.G. 1997a: Morphology and chaetotaxy of larval Hydraenidae (Coleoptera) III: The genus Calobius Wollaston, 1854. Aquat. Insects 19: 165-175.

Delgado J.A. \& Soler A.G. 1997b: Morphology and chaetotaxy of larval Hydraenidae (Coleoptera) II: The subgenus Ochthe- 
bius s. str. Leach. Bull. Inst. R. Sci. Nat. Belg. Entomol. 67: $45-55$.

Delgado J.A. \& Soler A.G. 1997c: Morphology and chaetotaxy of larval Hydraenidae (Coleoptera) I: genus Limnebius Leach, 1815 based on a description of Limnebius cordobanus d'Orchymont. Aquat. Insects 19: 37-49.

Delgado J.A., Collantes F. \& Soler A.G. 1998: Descripción de los tres estadios larvarios de Aulacochthebius exaratus (Mulsant, 1844) (Coleoptera, Hydraenidae). Zool. Baetica 9: $35-45$.

Dyвas H.S. 1976: The larval character of featherwing and limulodid beetles and their family relationships in the Staphylinoidea (Coleoptera: Ptiliidae and Limulodidae). Fieldiana (Zool.) 70(3): 29-78.

FARRIS J.S. 1988: Hennig86, version 1.5. Distributed by the author, Port Jefferson Station, N.Y.

Grebennikov V.V. \& Beutel R.G. 2002: Morphology of the minute larva of Ptinella tenella, with special reference to effects of miniaturisation and systematic position of Ptiliidae (Coleoptera: Staphylinoidea). Arthropod Struct. Dev. 31: 157-172.

Hansen M. 1991: A review of the genera of the beetle family Hydraenidae (Coleoptera). Steenstrupia 17(1): 1-52.

Hansen M. 1996: Coleoptera Hydrophiloidea and Hydraenidae, water scavenger beetles. In Nilsson A.N. (ed.): Aquatic Iin- sects of North Europe. A Taxonomic Handbook. Vol. 1. Apollo Books, Stenstrup, pp. 173-194.

Hansen M. 1998: World Catalogue of Insects. 1. Hydraenidae (Coleoptera). Apollo Books, Stenstrup, 168 pp.

Nixon K.C. 1999: Winclada, version 0.9.9. Published by the author, Ithaca, NY.

Perkins P.D. 1980: Aquatic beetles of the family Hydraenidae in the western hemisphere: Classification, biogeography and inferred phylogeny (Insecta: Coleoptera). Quaest. Entomol. 16: $3-554$.

Perkins P.D. 1997: Life in the efective bubble: Exocrine secretions delivery system (ESDS) and the evolution and classification of beetles in the family Hydraenidae (Insecta: Coleoptera). Ann. Carnegie Mus. 66(2): 89-207.

Perkins P.D. \& Archangelsky M. 2002: A new species of water beetle from Ischigualasto Park, Argentina (Coleoptera: Hydraenidae). Coleopt. Bull. 56: 237-240.

Richmond E.A. 1920: Studies on the biology of aquatic Hydrophilidae. Bull. Am. Mus. Nat. Hist. 42: 1-94.

SwOFFord D.L. 2002: PAUP*. Phylogenetic Analysis Using Parsimony (and other Methods). Version 4.0b10. Sinauer Associates, Inc., Sunderland, Massachusetts.

Received September 8, 2004; revised and accepted December 8, 2004 